\section{High Temperature Inhibits Germination of Jalapeño and Cayenne Pepper}

\author{
Anne K. Carter ${ }^{1}$ \\ Department of Plant and Soil Sciences, University of Massachusetts, Amherst, \\ MA 01003-0910
}

Charles S. Vavrina ${ }^{2}$

University of Florida, Southwest Florida Research and Education Center, Immokalee, FL 33934

Additional index words. Capsicum annuum, seed germination, stand establishment, thermodormancy, thermoinhibition

\begin{abstract}
The germination of five commercial cultivars of jalapeño and cayenne pepper were tested to determine cultivar response of Capsicum annuum $\mathrm{L}$. to supra-optimal temperatures. Two seedlots of 'Cayenne, Large Red Thick', 'Ole', 'Jalapeño M', 'Mitla', and 'Tam Veracruz' were evaluated on a thermogradient table at temperatures of 20, 25, 30,35 , and $40{ }^{\circ} \mathrm{C}$. Percent germination and time to $50 \%$ of final germination $\left(\mathrm{T}_{50}\right)$ were calculated. All cultivars exhibited thermodormancy, but the degree of inhibition varied within temperature and cultivar. No cultivar had $>1.0 \%$ germination at $40{ }^{\circ} \mathrm{C}$. Generally, the $T_{50}$ varied among cultivars, but not among temperatures within a cultivar $\left(T_{50}\right.$ at $40^{\circ} \mathrm{C}$ was not measured). Cultivar selection should be considered when growing fall transplants in Florida.
\end{abstract}

In the southern United States, thousands of acres of peppers are planted commercially in the fall and spring. Fall production accounts for much of the acreage of jalapeño peppers. However, seed for fall transplants is sown when summer greenhouse temperatures can reach 40 to $45^{\circ} \mathrm{C}$ for $6 \mathrm{~h}$ or more (Vavrina, 1994). This is far above the optimum temperature $\left(29^{\circ} \mathrm{C}\right)$ for pepper germination (Maynard and Hochmuth, 1997). Shade cloth and traytop dressings of vermiculite or perlite to cool the germination medium may not prevent inhibited or erratic germination. Erratic germination causes various production schedule complications and often reduces overall stand establishment.

The inability to germinate at higher than optimal temperatures is attributed to a condition called thermoinhibition. Tomato (Lycopersicon esculentum Mill.) seeds do not germinate at high temperatures $\left(\geq 35^{\circ} \mathrm{C}\right)$, but do germinate after temperature is reduced to

Received for publication 7 Aug 2000. Accepted for publication 21 Nov. 2000. Research was conducted at the Univ. of Florida, Southwest Florida Research and Education Center, Immokalee, and was based upon work supported by the Cooperative State Research, Extension, Education Service, U.S. Dept. of Agriculture, Massachusetts Agricultural Experiment Station, under Project No. MAS00786. Use of trade names does not imply endorsement of the products named nor criticism of similar ones not named. The cost of publishing this paper was defrayed in part by the payment of page charges. Under postal regulations, this paper therefore must be hereby marked advertisement solely to indicate this fact.

${ }^{1}$ Extension Assistant Professor. E-mail address: akcarter@pssci.umass.edu

${ }^{2}$ Associate Professor.
$25{ }^{\circ} \mathrm{C}$ or $30{ }^{\circ} \mathrm{C}$ (Abebe, 1993). Thermoinhibition also occurs in other vegetable seeds, such as celery [Apium graveolens L. dulce (Mill) Pers.] (Biddington 1981), lettuce (Lactuca sativa L.) (Borthwick and Robbins, 1928; Khan, 1980/1981), and spinach (Spinacia oleracea L.) (Harrington, 1963; Leskovar et al., 1999). In lettuce, thermotolerance differs among cultivars (Damania, 1986; Gray, 1975; Thompson, 1979); this has been attributed to the degree of endo- $\beta$-mannanase activity in the seeds (Nascimento et al., 2000).

Pepper seed germination was improved under supra-optimal conditions if the seeds were first soaked in solutions of ethephon or gibberellic acid $\left(\mathrm{GA}_{3}\right)$ (Carter and Stevens, 1998). However, priming incurs additional costs and time considerations. A knowledge of which cultivars can germinate under supraoptimal conditions might be a more acceptable approach for transplant producers. Germination does not necessarily equate with stand establishment, but defining whether poor stand establishment is due to inhibition of germination or poor seedling growth is a logical first step. The purpose of this study was to survey the effect of temperature on the germination of different cultivars of jalapeño and cayenne pepper (Capsicum annuum L.) used commercially in Florida.

Seed sources. Five commercial cultivars of cayenne or jalapeño pepper were chosen based on the ability to obtain two seedlots of each cultivar. Seeds of 'Ole' (15759-27420 and 15759-34420; Ferry Morse Seed Co., Modesto, Calif.); 'Jalapeño M' (057-014-1168 and 057014-1188; PetoSeed Co., Saticoy, Calif.); 'Mitla' (007-104-1515 and 007-104-1516; PetoSeed Co.); 'TAM Veracruz' (057-674-
1024 and 057-674-1027; PetoSeed Co.); and 'Cayenne, Large Red Thick' (1163 and 1169; PetoSeed Co.) were used. 'Ole' and 'Mitla' are $F_{1}$ hybrids while 'Jalapeño M', 'TAM Veracruz', and 'Cayenne, Large, Red Thick' are open-pollinated.

Seed germination. Germination temperatures of $20,25,30,35$, or $40{ }^{\circ} \mathrm{C}$ were maintained on a one-dimensional, linear thermogradient table (Van dok and De boer Machinefabriek b.v., Enkhuizen, The Netherlands). Four replicates of 25 seeds each were placed on two layers of filter paper (W\&R Balston L. Genuine Whatman, England) in separate $9-\mathrm{cm}$-diameter petri dishes. The filter paper was wetted with $10 \mathrm{~mL}$ of distilled water. Evaporation rates at $35^{\circ} \mathrm{C}$ and $40{ }^{\circ} \mathrm{C}$ required the addition of $4 \mathrm{~mL} \mathrm{H}_{2} \mathrm{O}$ every $2 \mathrm{~d}$ for these two treatments. The four replications of each of the 10 seedlots were completely randomized within each temperature treatment. The entire experiment was repeated twice.

Germination was recorded daily until the remaining seeds began to deteriorate ( $16 \mathrm{~d})$. A seed was considered germinated when the radicle had elongated $\geq 2 \mathrm{~mm}$ from the seed coat. Total percentage of germination and time to $50 \%$ of final germination $\left(\mathrm{T}_{50}\right)$ were calculated. Statistical analysis and mean separation were calculated using SAS statistical software (SAS Institute, Cary, N.C.).

Differences between the two experiments were nonsignificant, so the data were combined in a pooled analysis. Mean square errors were calculated by hand, then an F test was performed using the appropriate degrees of freedom.

Germination of 'Jalapeño M', 'Mitla', and 'TAM Veracruz' was nearly $100 \%$ from 20 to $30{ }^{\circ} \mathrm{C}$ (Fig. 1A). At $35^{\circ} \mathrm{C}$, germination of 'TAM Veracruz' decreased to $48 \%$ while that of 'Jalapeno M' and 'Mitla' dropped to $82 \%$ and $72 \%$, respectively. Germination of 'Cayenne, Large, Red Thick' and 'Ole' was below $25 \%$ at $35^{\circ} \mathrm{C}$. Germination of all cultivars was $\leq 1 \%$ germination at $40^{\circ} \mathrm{C}$. The critical maximum (Harrington, 1963) for germination appeared to be between 30 and $35^{\circ} \mathrm{C}$. Germination of 'Ebano' had $95 \%$ germination at 35 ${ }^{\circ} \mathrm{C}$, but again gemination dropped to $1 \%$ at 40 ${ }^{\circ} \mathrm{C}$ (data not shown). Cultivar differences in germination response to temperature have been reported in lettuce (Perkins-Veazie and Cantliffe, 1984; Prusinski and Khan, 1990; Thompson et al., 1979) and spinach (Atherton and Farooque, 1983; Leskovar et al., 1999). Germination of 'Packman' broccoli (Brassica oleracea L., Botrytis group) decreased from $90 \%$ to $63 \%$ at $35^{\circ} \mathrm{C}$ when the germination of this cultivar was tested at a range between 5 and $40{ }^{\circ} \mathrm{C}$ (Elson et al., 1992).

Germination differences were also evident between seedlots of the same cultivar (data not shown); however, making generalizations about seedlot differences is inappropriate when only two seedlots of each cultivar were tested. Since growers and seed producers expect consistency within a cultivar from season to season, seedlot variation should be noted. Demir (1992) showed that variation in pepper seed quality resulted from differences in seed de- 

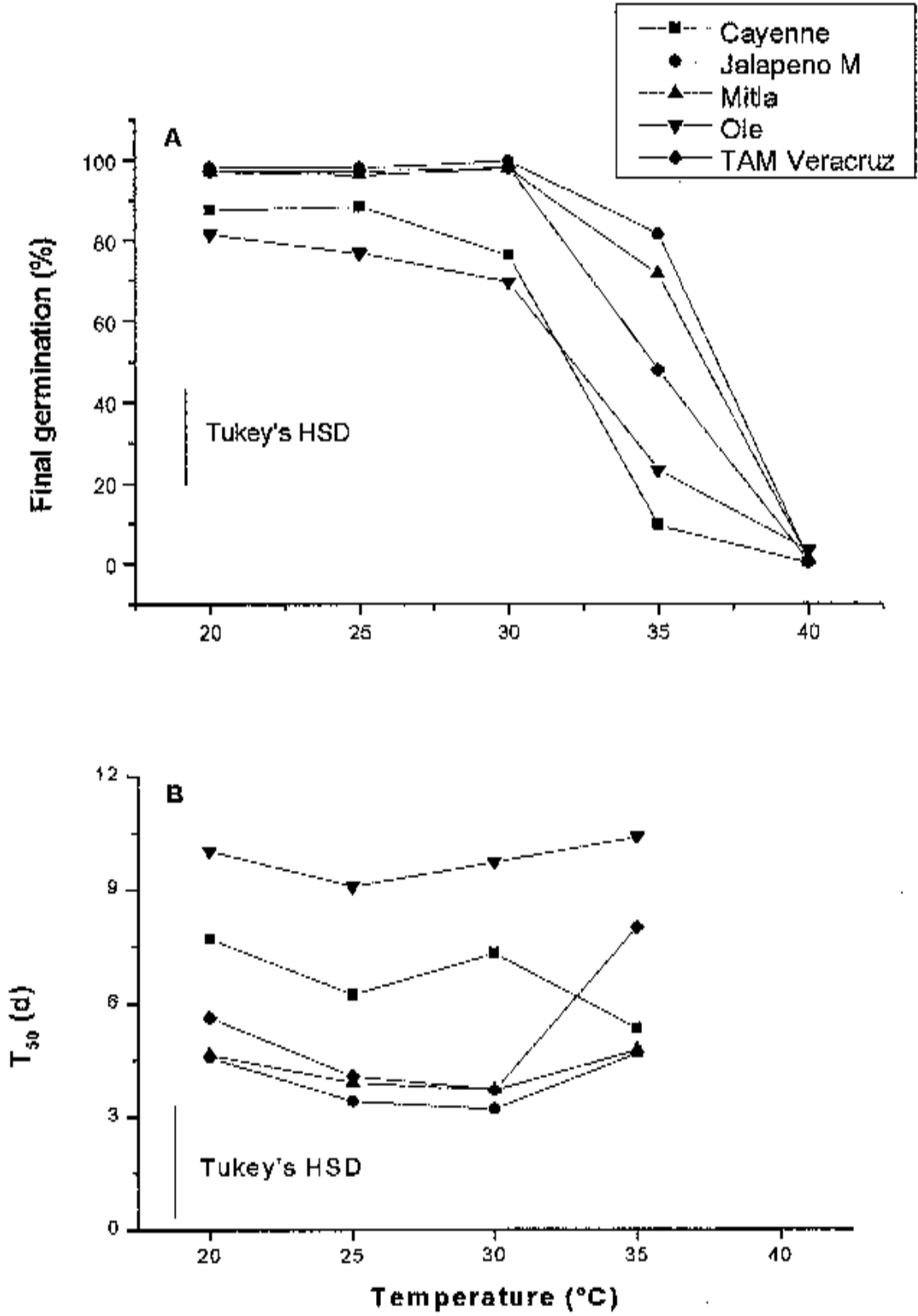

Fig. 1. Germination of seeds of five cultivars of pungent pepper at five different temperatures. (A) final germination (\%) or $(\mathbf{B})$ time to $50 \%$ of final germination $\left(\mathrm{T}_{50}\right)$. In $(\mathbf{B}), \mathrm{T}_{50}$ at $40{ }^{\circ} \mathrm{C}$ is not shown because germination at that temperature was near zero for all treatments. Tukey's HSD, $P \leq 0.05, n=16$.

velopmental age and storage conditions and that this could vary from one seedlot to another.

Temperature had little affect on the time to $50 \%$ of final germination for each of the five cultivars (Fig. 1B). Only in 'TAM Veracruz' $\operatorname{did} \mathrm{T}_{50}$ increase between 30 and $35^{\circ} \mathrm{C}$. The $\mathrm{T}_{50}$ varied among cultivars from 4 to $10 \mathrm{~d}$ at temperatures between 20 and $35^{\circ} \mathrm{C}$; the $\mathrm{T}_{50}$ was not calculated for $40^{\circ} \mathrm{C}$, as germination percentages were $\leq 1 \%$ for all cultivars. Differ-

\section{Literature Cited}

Abebe, Y. 1993. Improving tomato (Lycopersicon esculentum Mill.) seed germination under high temperature by seed priming, scarification, heatshock, and light. MS Thesis, Hort. Sci. Dept. Univ. of Florida, Gainesville.

Atherton, J.G. and A.M. Farooque. 1983. High temperature and germination in spinach. II. Effects of osmotic priming. Scientia Hort. 19:221227.

Biddington, N.L. 1981. Thermodormancy and the prevention of desiccation injury in celery seeds. Ann. Appl. Biol. 98:558-562.

Borthwick, H.A. and W.W. Robbins. 1928. Lettuce seed and its germination. Hilgardia 31:275305.

Carter, A.K. and R. Stevens. 1998. Using ethephon and $\mathrm{GA}_{3}$ to overcome thermoinhibition in 'Jalapeno M' pepper seed. HortScience 33:10261027.

Damania, A.B. 1986. Inhibition of seed germination in lettuce at high temperature. Seed Res. 14:177184

Demir, I. and R.H. Ellis. 1992. Development of pepper seed quality. Ann. Appl. Biol. 121:385399.

Elson, M.K., R.D. Morse, D.D. Wolf, and D.H. Vaughn. 1992. High temperature inhibition of seed germination and seedling emergence of broccoli. HortTechnology 2:417-419.

Gray, D. 1975. Effects of temperature on the germination and emergence of lettuce (Lactuca sativa) cultivars. HortScience 50:349-361.

Harrington, J.F. 1963. The effect of temperature on germination of several kinds of vegetable seeds, p. 431-441. In: A. Lecrenier and P. Goessels (eds.). Proc. XVI Intl. Hort. Congr. vol. 2. Dulcot, Brussels.

Khan, A.A. 1980/1981. Hormonal regulation of primary and secondary seed dormancy. Israel J. Bot. 29:207-224.

Leskovar, D.I., V. Esensee, and H. Belefant-Miller. 1999. Pericarp, leachate, and carbohydrate involvement on thermoinhibition of germinating spinach seeds. J. Amer. Soc. Hort. Sci. 124:301306.

Maynard, D.N. and G.J. Hochmuth. 1997. Knott's Handbook for Vegetable Growers. 4th Ed. Wiley, New York.

Nascimento, W.M., D.J. Cantliffe, and D.J. Huber. 2000. Thermotolerance in lettuce seeds: Association with ethylene and endo- $\beta$-mannanase. J. Amer. Soc. Hort. Sci. 125:518-524.

Perkins-Veazie, P. and D.J. Cantliffe. 1984. Need for high quality seed for effective priming to overcome thermodormancy in lettuce. J. Amer. Soc. Hort. Sci. 109:368-372.

Prusinski, J. and A.A. Khan. 1990. Relationship of ethylene production to stress alleviation in seeds of lettuce cultivars. J. Amer. Soc. Hort. Sci. 115:294-298

Thompson, P.A., S.A. Cox, and R.H. Sanderson. 1979. Characterization of the germination responses to temperature of lettuce (Lactuca sativa L.) achenes. Ann. Bot. 43:319-334.

Vavrina, C.S. 1994. Plastic tray inserts. Florida Veg. Transplant Growers News. 5:3. 